\title{
Triterpenoids from Cyclocarya paliurus that Enhance Glucose Uptake in 3T3-L1 Adipocytes
}

\author{
Zhu-Jun Fang ${ }^{1,+}$, Sheng-Nan Shen ${ }^{2,+}$, Jia-Min Wang ${ }^{1}$, Yong-Jiang $\mathrm{Wu}^{1}{ }^{1}$, Chang-Xin Zhou ${ }^{1}$, \\ Jian-Xia Mo ${ }^{1}$, Li-Gen Lin ${ }^{2, *(D)}$ and Li-She Gan 1,3,* \\ 1 College of Pharmaceutical Sciences, Zhejiang University, 866 Yuhangtang Road, Hangzhou 310058, China; \\ 11519027@zju.edu.cn (Z.-J.F.); 21819075@zju.edu.cn (J.-M.W.); yjwu@zju.edu.cn (Y.-J.W.); \\ zhoucx10@zju.edu.cn (C.-X.Z.); mojx@zju.edu.cn (J.-X.M.) \\ 2 State Key Laboratory of Quality Research in Chinese Medicine, Institute of Chinese Medical Sciences, \\ University of Macau, Macao 999078, China; yb57518@um.edu.mo \\ 3 Hangzhou Institute of Innovative Medicine, Zhejiang University, 291 Fucheng Road, \\ Hangzhou 310018, China \\ * $\quad$ Correspondence: ligenl@um.edu.mo (L.-G.L.); lsgan@zju.edu.cn (L.-S.G.); Tel.: +86-571-8820-8457 (L.-S.G.) \\ + These authors contributed equally to this work.
}

Received: 8 December 2018; Accepted: 30 December 2018; Published: 6 January 2019

check for updates

\begin{abstract}
Four previously undescribed compounds, including three rarely occurring seco-dammarane triterpenoid glycosides and a pentacyclic triterpenic acid, were isolated from a $70 \%$ ethanol extract of the leaves of Cyclocarya paliurus (Juglandaceae), along with eleven known triterpenoids. Their structures were determined by spectroscopic techniques, including 2D NMR and HRESIMS, as well as chemical methods. Among them, several triterpenoids enhanced insulin stimulated glucose uptake in both 3T3-L1 adipocytes and C2C12 myotubes. Furthermore, compound 1 dose-dependently increased glucose uptake through activating AMP-activated protein kinase (AMPK)-p38 pathway. Collectively, triterpenoids from C. paliurus could be developed as insulin sensitizers, which might have therapeutic potential for insulin resistance and hyperglycemia.
\end{abstract}

Keywords: Cyclocarya paliurus (Juglandaceae); seco-dammarane triterpenoids; glucose uptake; adipocytes

\section{Introduction}

Long-term use of oral hypoglycemic agents or insulin is accompanied by side effects, including hypoglycemic episodes, edema, hepatorenal disturbances, and gastrointestinal problems [1,2]. Due to their perceived better safety and efficacy, phytochemicals such as phenolic acids, flavonoids, alkaloids, polysaccharides, and triterpenoids have attracted more and more attention in the treatment of diabetes [3]. Many triterpenoids have been revealed to possess potential therapeutical effects to treat diabetes. Cucurbitane-type triterpenoids were reported to improve insulin sensitivity and glucose homeostasis in C2C12 myotubes and a streptozotocin (STZ)-induced diabetic mouse model [4]. Nanoencapsulated triterpenoids from Petri dish-cultured Antrodia cinnamomea ameliorate hyperglycemia on high-fat diet (HFD)- and STZ-induced diabetic rats [5]. The extract of a triterpenoid-enriched Jamun fruit attenuates hyperglycemia and glucose intolerance, prevents the abnormal elevation of hepatic gluconeogenesis, and improves dyslipidemia in STZ-induced diabetic mice [6]. Ursolic acid was evaluated to improve insulin sensitivity and promote glucose uptake and utilization $[7,8]$.

Cyclocarya paliurus (Batalin) Iljinsk., a Chinese endemic plant, belongs to the family Juglandaceae and is mainly distributed in South and Southeast China [9]. Its leaves have been used as folk medicines for the prevention and treatment of diabetes mellitus, hypertension and dyslipidemia [10] and approved as a new food material by the China FDA in 2014. To date, triterpenoids, flavonoids, phenolic 
acids, and polysaccharides have been isolated from this plant [11-14]. Previous studies revealed that C. paliurus ethanol extract exhibits antihyperglycemic effects, and ameliorates insulin resistance in type 2 diabetic rats $[15,16]$, in which triterpenoids might be the major functional components $[17,18]$. For example, cyclocaric acid B and cyclocarioside $\mathrm{H}$ promote glucose uptake in the absence of insulin, as well as ameliorate insulin receptor substrate 1 (IRS-1)/phosphoinositide 3-kinase (PI3K)/protein kinase B (Akt) pathway by inhibiting inflammation in 3T3-L1 adipocytes [19].

In a continuing search for insulin sensitizing compounds from C. paliurus, four undescribed compounds 1-4 (Figure 1), including three rarely occurring seco-dammarane triterpenoid glycosides 1-3 possessing 20,24-epoxy linkages, and a pentacyclic triterpenic acid 4, were systematically isolated, along with eleven known triterpenoids 5-15. Their structures were elucidated on the basis of chemical and spectroscopic approaches, including 2D NMR and HRESIMS techniques. Finally the effects of the isolates in insulin-stimulated glucose uptake in 3T3-L1 adipocytes and C2C12 myotubes were further evaluated.

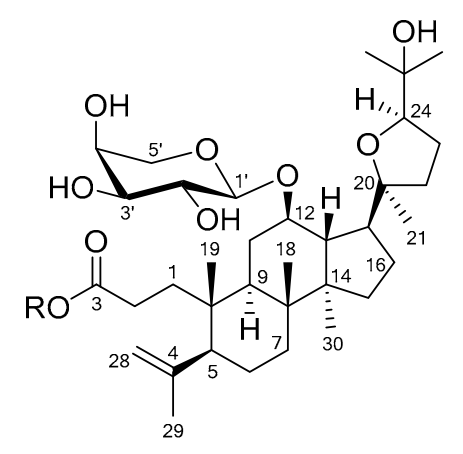

$1 \mathrm{R}=\mathrm{H}$ $2 \mathrm{R}=\mathrm{CH}_{3}$

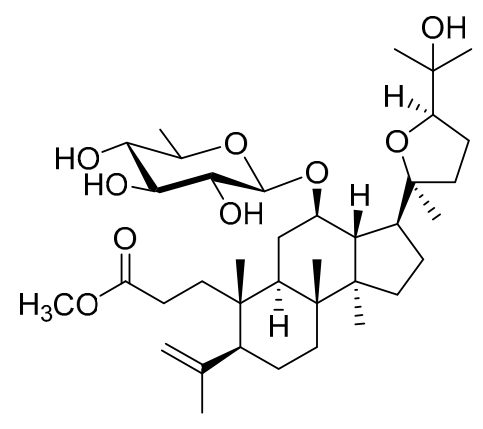

3

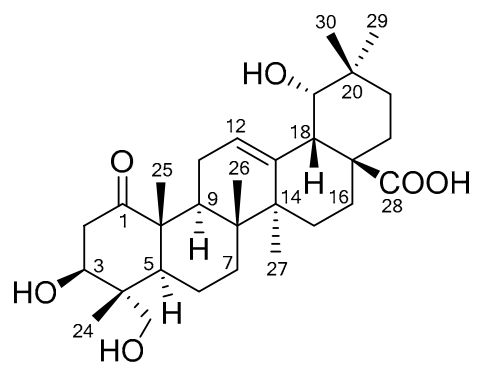

4

Figure 1. Chemical structures of compounds 1-4.

\section{Results and Discussion}

\subsection{Identification of New Compounds}

Compound 1 was isolated as a white amorphous powder, which had a molecular formula of $\mathrm{C}_{35} \mathrm{H}_{58} \mathrm{O}_{9}$ as deduced from a HRESIMS pseudo ion peak at 645.3978 [M $+\mathrm{Na}^{+}$(calcd. for $\mathrm{C}_{35} \mathrm{H}_{58} \mathrm{O}_{9} \mathrm{Na}$, 645.3979). The IR spectrum showed absorption bands for carboxyl $\left(1699 \mathrm{~cm}^{-1}\right.$ and $\left.3405 \mathrm{~cm}^{-1}\right)$ and double bond $\left(1685 \mathrm{~cm}^{-1}\right)$ functions. The ${ }^{1} \mathrm{H}-\mathrm{NMR}$ spectrum (Table 1 ) of 1 exhibited seven methyl singlets at $\delta_{\mathrm{H}} 1.00(\mathrm{~s}, \mathrm{Me}-30), 1.77$ (s, Me-29), 1.16 (s, Me-27), 1.19 (s, Me-26), 1.16 (s, Me-21), 1.10 (s, Me-19), and 1.06 (s, Me-18), as well as terminal methylene olefinic protons at $\delta_{\mathrm{H}} 4.72(\mathrm{~d}, J=1.4 \mathrm{~Hz}, \mathrm{H}-28 \mathrm{a})$ and $4.85(\mathrm{~d}, J=1.4 \mathrm{~Hz}, \mathrm{H}-28 \mathrm{~b})$. The ${ }^{13} \mathrm{C}-\mathrm{NMR}$ (Table 1) and DEPT (135) spectra revealed a carboxyl group at $\delta_{C} 180.2$, one terminal double bond at $\delta_{C} 149.3$ and 114.1, and four oxygen-bearing carbons at $\delta_{C} 76.5$ (C-12), 87.8 (C-20), 84.9 (C-24), and 72.7 (C-25). Besides, the presence of an anomeric hydrogen at $\delta_{\mathrm{H}} 4.29\left(\mathrm{~d}, J=7.1 \mathrm{~Hz}, \mathrm{H}-1^{\prime}\right)$ in the ${ }^{1} \mathrm{H}-\mathrm{NMR}$ spectrum and five carbon signals at $\delta_{C} 101.2,72.8,74.6,70.4$, and 67.8 indicated an arabinosyl moiety. The above data suggested an unusual 3,4-seco-dammarane type triterpenoid glycoside structurefor 1, similar to that of the known compound cyclocarioside F [14], except for signals of the side-chain. In the HMBC spectrum (Figure 2), the seco-dammarane skeleton was confirmed by correlations from $\mathrm{H}_{3}-29$ to $\mathrm{C}-4, \mathrm{C}-5$, and $\mathrm{C}-28$, from $\mathrm{H}_{2}-2$ to $\mathrm{C}-1$ and $\mathrm{C}-3$, from $\mathrm{H}_{3}-19$ to $\mathrm{C}-1, \mathrm{C}-5, \mathrm{C}-9$, and $\mathrm{C}-10$, from $\mathrm{H}_{3}-21$ to $\mathrm{C}-17, \mathrm{C}-20$, and $\mathrm{C}-22$, from $\mathrm{H}_{3}-18$ to $\mathrm{C}-7, \mathrm{C}-8, \mathrm{C}-9$, and $\mathrm{C}-14$, and from $\mathrm{H}_{3}-30$ to $\mathrm{C}-8, \mathrm{C}-13, \mathrm{C}-14$, and $\mathrm{C}-15$. Key correlations from $\mathrm{H}-24$ to $\mathrm{C}-20$, and from $\mathrm{H}_{3}-27$ to $\mathrm{C}-24$ and $\mathrm{C}-25$ verified the 20,24-epoxy linkage and an additional hydroxyl group linked to C-25. Furthermore, a significant HMBC correlation between the anomeric hydrogen $\mathrm{H}-1^{\prime}$ and $\mathrm{C}-12$ placed the glycoside moiety properly. Moreover, the pentose moiety was assigned as $\alpha$-L-arabinopyranosyl based on the NMR data and comparison with those dammarane 
derivatives from this plant $[14,20,21]$, as well as further acid hydrolysis and co-TLC with an authentic L-arabinose sample [22]. The relative configuration of $\mathbf{1}$ was determined by NOESY experiments (Figure 2). Strong NOESY correlations of $\mathrm{H}-5 / \mathrm{H}-9, \mathrm{H}-9 / \mathrm{H}_{3}-30, \mathrm{H}-17 / \mathrm{H}_{3}-30$, and $\mathrm{H}-12 / \mathrm{H}-17$ indicated that $\mathrm{H}-5, \mathrm{H}-9, \mathrm{H}-12, \mathrm{H}-17$, and $\mathrm{H}_{3}-30$ are $\alpha$-oriented. The $\beta$-orientation of $\mathrm{H}-13, \mathrm{H}_{3}-18$, and $\mathrm{H}_{3}-19$ were then verified by NOESY correlations of $\mathrm{H}-13 / \mathrm{H}_{3}-18$ and $\mathrm{H}_{3}-18 / \mathrm{H}_{3}-19$. Because free rotation of the C-17-C-20 single bond was restricted to some extent in these triterpenoids with a 20,24-epoxyside chain $[14,20]$, the configurations at C-20 and C-24 were then determined to be $20 S$ and $24 R$ based on key NOESY correlations of $\mathrm{H}-17 / \mathrm{H}_{3}-21$ and $\mathrm{H}_{3}-21 / \mathrm{H}-24$, respectively. As the absolute configuration on the main skeleton of these seco-dammarane triterpenoids have already been clarified by techniques such as single-crystal $\mathrm{X}$-ray diffraction analysis with $\mathrm{Cu} \mathrm{K \alpha}$ irradiation [23], compound $\mathbf{1}$ was identified as (20S,24R)-20,24-epoxy-25-hydroxy-12 $\beta$-( $\alpha$-L-arabinopyranosyloxy)-3,4-seco-dammara-4(28)-en-3-oic acid.

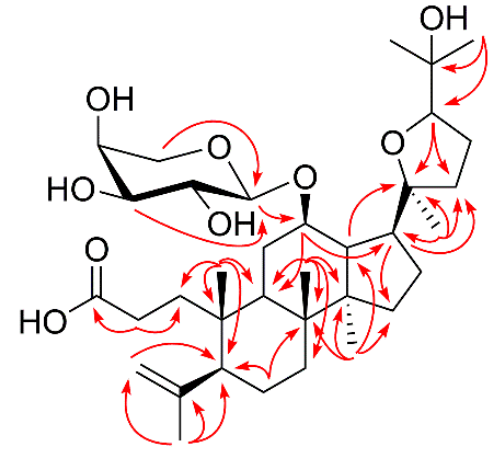

Figure 2. Key HMBC (red arrows) and NOESY (blue dotted double arrows) correlations of $\mathbf{1}$.

Compound 2 exhibited a molecular formula of $\mathrm{C}_{36} \mathrm{H}_{60} \mathrm{O}_{9}$ based on its HRESIMS data. The NMR spectrum (Table 1) of $\mathbf{2}$ showed high similarities to that of $\mathbf{1}$ except for an additional methoxy group, as indicated by a ${ }^{1} \mathrm{H}-\mathrm{NMR}$ methyl singlet at $\delta_{\mathrm{H}} 3.64\left(3 \mathrm{H}, \mathrm{s}, \mathrm{OCH}_{3}\right)$ and one ${ }^{13} \mathrm{C}-\mathrm{NMR}$ carbon signal at $\delta_{\mathrm{C}} 52.1\left(\mathrm{OCH}_{3}\right)$. Furthermore, an $\mathrm{HMBC}$ correlation between $\mathrm{OCH}_{3}$ and $\mathrm{C}-3$ revealed that 2 was a 3-methyl ester derivative of $\mathbf{1}$. The configuration of $\mathbf{2}$ was further confirmed the same as $\mathbf{1}$ by NOESY experiments. Ultimately, the structure of 2 was elucidated as $(20 S, 24 R)-20,24-e p o x y-25-$ hydroxy-12 $\beta$-( $\alpha$-L-arabinopyranosyloxy)-3,4-seco-dammara-4(28)-en-3-oic acid methyl ester.

Compound 3 is a white amorphous powder. Its molecular formula was established as $\mathrm{C}_{37} \mathrm{H}_{62} \mathrm{O}_{9}$ by HRESIMS $\left(\mathrm{m} / z\right.$ 673.4288 $[\mathrm{M}+\mathrm{Na}]^{+}$, calcd for $\left.\mathrm{C}_{37} \mathrm{H}_{62} \mathrm{O}_{9} \mathrm{Na}, 673.4292\right)$ and ${ }^{13} \mathrm{C}-\mathrm{NMR}$ data (Table 1). The 1D NMR data (Table 1) were almost identical to those of 2 except for the replacement of the arabinopyranosyl moiety in 2 by a quinovopyranosyl unit in 3 . The sugar linkage at $\mathrm{C}-12$ was deduced by the HMBC correlation between $\mathrm{H}-1^{\prime}\left(\delta_{\mathrm{H}} 4.36\right)$ and $\mathrm{C}-12\left(\delta_{\mathrm{C}} 76.5\right)$. The closely comparable NMR spectra for the sugar moiety of 3 to those of co-isolated known compounds 12, 13, 14, and 15, and the previously reported dammarane derivativesfrom this plant $[14,20,21]$, together with an acid hydrolysis experiment and co-TLC with an authentic D-quinovose sample [22], suggested that the same $\beta$-D-quinovopyranosyl unit in 3 . The configuration of 3 was also confirmed by NOESY experiment. Therefore, compound 3 was characterized as (20S,24R)-20,24-epoxy-25-hydroxy-12 $\beta$-( $\beta$-D-quinovopyranosyloxy)-3,4-seco-dammara-4(28)-en-3-oic acid methyl ester. 
Table 1. ${ }^{1} \mathrm{H}-(500 \mathrm{MHz}, \delta$ in ppm, $J$ in $\mathrm{Hz})$ and ${ }^{13} \mathrm{C}-\mathrm{NMR}(125 \mathrm{MHz}, \delta$ in ppm) data of compounds 1-4 in $\mathrm{CD}_{3} \mathrm{OD}$.

\begin{tabular}{|c|c|c|c|c|c|c|c|c|}
\hline \multirow{2}{*}{ No. } & \multicolumn{2}{|l|}{1} & \multicolumn{2}{|l|}{2} & \multicolumn{2}{|l|}{3} & \multicolumn{2}{|l|}{4} \\
\hline & $\delta_{H}$ & $\delta_{C}$ & $\delta_{H}$ & $\delta_{C}$ & $\delta_{\mathrm{H}}$ & $\delta_{\mathrm{C}}$ & $\delta_{H}$ & $\delta_{C}$ \\
\hline 1 & a $1.53, \mathrm{~m}$ & 38.4 & a $1.47, \mathrm{~m}$ & 38.3 & a $1.42, \mathrm{~m}$ & 38.0 & & 215.4 \\
\hline 2 & $\begin{array}{c}\text { a } 2.26, \mathrm{~m} \\
\text { b } 2.66 . \mathrm{dt}(12.9,5.2)\end{array}$ & 30.8 & a $2.29, \mathrm{dt}(13.3,3.5)$ & 30.7 & $\begin{array}{l}\text { a } 2.27, \mathrm{dt}(13.3,3.3) \\
\text { b } 2.74 \mathrm{dt}(13.3,5.1)\end{array}$ & 30.5 & $\begin{array}{c}\alpha 2.29, \mathrm{dd}(11.9,4.9) \\
33.12 \mathrm{t}(11.9)\end{array}$ & 44.8 \\
\hline 3 & D 2.00, ut (12.), 5.2$)$ & 180.2 & $02.74, \mathrm{Cl}(10.0,5.0)$ & 178.3 & & 177.9 & $3.82, \mathrm{dd}(12.1,4.9)$ & 73.5 \\
\hline 4 & & 149.3 & & 149.3 & & 149.3 & & 44.1 \\
\hline 6 & $\beta 1.45, \mathrm{~m}$ & & $\beta 1.49, \mathrm{~m}$ & & $\beta 1.47, \mathrm{~m}$ & & $\beta 1.57, \mathrm{~m}$ & \\
\hline \multirow[t]{2}{*}{7} & $\alpha 1.59, \mathrm{~m}$ & 35.8 & $\alpha 1.59, \mathrm{dt}(13.0,3.3)$ & 35.8 & $\alpha 1.59, \mathrm{dt}(12.9,3.3)$ & 35.7 & $\alpha 1.55, \mathrm{~m}$ & 33.3 \\
\hline & $\beta 1.22, \mathrm{~m}$ & & $\beta 1.21, \mathrm{~m}$ & & $\beta 1.22, \mathrm{~m}$ & & $\beta 1.29, \mathrm{~m}$ & \\
\hline 8 & & 40.9 & & 40.9 & & 40.9 & & 40.5 \\
\hline 9 & $1.95, \mathrm{~m}$ & 45.4 & $1.95, \mathrm{~m}$ & 45.4 & $1.93, \mathrm{~m}$ & 45.5 & $2.40, \mathrm{~m}$ & 40.8 \\
\hline 10 & & 41.9 & & 41.9 & & 41.9 & & 53.6 \\
\hline 14 & & 51.4 & & 51.4 & & 51.4 & & 42.8 \\
\hline \multirow[t]{2}{*}{15} & $\alpha 1.49, \mathrm{~m}$ & 32.3 & $\alpha 1.44, \mathrm{~m}$ & 32.3 & $\alpha 1.45, \mathrm{~m}$ & 32.4 & $\alpha 1.00, \mathrm{~m}$ & 29.6 \\
\hline & $\beta 1.13, \mathrm{~m}$ & & $\beta 1.12, \mathrm{~m}$ & & $\beta 1.12, \mathrm{~m}$ & & $\beta 1.72, \mathrm{~m}$ & \\
\hline \multirow[t]{2}{*}{16} & $\alpha 1.99, \mathrm{~m}$ & 27.1 & $\alpha 1.98, \mathrm{~m}$ & 27.1 & $\alpha 1.98, \mathrm{~m}$ & 27.0 & $\alpha 2.25, \mathrm{~m}$ & 28.7 \\
\hline & $\beta 1.81, \mathrm{~m}$ & & $\beta 1.80, \mathrm{~m}$ & & $\beta 1.80, \mathrm{~m}$ & & $\beta 1.59 . \mathrm{m}$ & \\
\hline 17 & $1.92, \mathrm{~m}$ & 50.2 & $1.93, \mathrm{~m}$ & 50.2 & $1.92, \mathrm{~m}$ & 50.1 & & 47.0 \\
\hline 18 & $1.06, \mathrm{~s}$ & 16.9 & $1.05, \mathrm{~s}$ & 16.9 & $1.05, \mathrm{~s}$ & 16.8 & 3.06 , br s & 45.5 \\
\hline 19 & $1.10, \mathrm{~s}$ & 20.6 & $1.09, \mathrm{~s}$ & 20.6 & $1.09, \mathrm{~s}$ & 20.5 & 3.27, d (3.6) & 82.4 \\
\hline 20 & & 87.8 & & 87.8 & & 87.9 & & 36.1 \\
\hline \multirow[t]{2}{*}{21} & $1.16, \mathrm{~s}$ & 25.5 & $1.16, \mathrm{~s}$ & 25.5 & $1.16, \mathrm{~s}$ & 25.2 & $\alpha 1.64, \mathrm{~m}$ & 29.6 \\
\hline & & & & & & & $\beta 1.00, \mathrm{~m}$ & \\
\hline \multirow[t]{2}{*}{22} & $\alpha 1.73, \mathrm{~m}$ & 35.0 & $\alpha 1.74, \mathrm{~m}$ & 35.0 & $\alpha 1.73, \mathrm{~m}$ & 34.8 & $\alpha 1.62, \mathrm{~m}$ & 34.0 \\
\hline & $\beta 1.65, \mathrm{~m}$ & & $\beta 1.67, \mathrm{~m}$ & & $\beta 1.66, \mathrm{~m}$ & & $\beta 1.78, \mathrm{~m}$ & \\
\hline 29 & $1.77, \mathrm{~s}$ & 24.0 & $1.76, \mathrm{~s}$ & 24.0 & $1.76, \mathrm{~s}$ & 23.9 & $0.94, \mathrm{~s}$ & 28.7 \\
\hline 30 & $1.00, \mathrm{~s}$ & 16.9 & $1.00, \mathrm{~s}$ & 16.9 & $0.99, \mathrm{~s}$ & 16.9 & $0.97, \mathrm{~s}$ & 25.2 \\
\hline $1^{\prime}$ & $4.29, \mathrm{~d}(7.1)$ & 101.2 & $4.28, \mathrm{~d}(7.1)$ & 101.4 & $4.36, \mathrm{~d}(7.7)$ & 100.4 & & \\
\hline $2^{\prime}$ & 3.50, dd $(9.6,7.1)$ & 72.8 & 3.50 , dd $(9.6,7.1)$ & 72.8 & 3.18 , dd $(9.3,7.7)$ & 75.3 & & \\
\hline $3^{\prime}$ & 3.46 , dd $(9.6,3.3)$ & 74.6 & 3.46 , dd $(9.6,3.3)$ & 74.6 & $3.29, \mathrm{~m}$ & 77.8 & & \\
\hline $4^{\prime}$ & $3.77, \mathrm{~m}$ & 70.4 & $3.77, \mathrm{~m}$ & 70.3 & $3.00, t(9.1)$ & 77.1 & & \\
\hline \multirow[t]{2}{*}{$5^{\prime}$} & $3.54, \mathrm{dd}(12.7,0.8)$ & 67.8 & $3.54, \mathrm{dd}(12.7,1.1)$ & 67.7 & $3.26, \mathrm{~m}$ & 73.0 & & \\
\hline & 3.88, dd $(12.7,1.9)$ & & 3.88, dd $(12.7,1.9)$ & & & & & \\
\hline $6^{\prime}$ & & & & & $1.26, \mathrm{~d}(6.1)$ & 18.1 & & \\
\hline $\mathrm{OCH}_{3}$ & & & $3.64, \mathrm{~s}$ & 52.1 & $3.63, \mathrm{~s}$ & 52.0 & & \\
\hline
\end{tabular}

Compound 4 was obtained as a white amorphous powder. It showed a molecular formula of $\mathrm{C}_{30} \mathrm{H}_{46} \mathrm{O}_{6}$ on the basis of the HRESIMS $(\mathrm{m} / z \text { 525.3185 [M }+\mathrm{Na}]^{+}$, calcd for $\left.\mathrm{C}_{30} \mathrm{H}_{46} \mathrm{O}_{6} \mathrm{Na}, 525.3192\right)$. The IR absorption bands at 3414, 2946 and $1695 \mathrm{~cm}^{-1}$ indicated the presence of hydroxyl groups, aliphatic $\mathrm{C}-\mathrm{H}$ and carbonyl groups, respectively. In the ${ }^{1} \mathrm{H}-\mathrm{NMR}$ spectrum (Table 1 ), six methyl singlets at $\delta_{\mathrm{H}} 0.97\left(\mathrm{~s}, \mathrm{H}_{3}-30\right), 0.94\left(\mathrm{~s}, \mathrm{H}_{3}-29\right), 1.33\left(\mathrm{~s}, \mathrm{H}_{3}-27\right), 0.85\left(\mathrm{~s}, \mathrm{H}_{3}-26\right), 1.35\left(\mathrm{~s}, \mathrm{H}_{3}-25\right)$, and $0.88\left(\mathrm{~s}_{1} \mathrm{H}_{3}-24\right)$, an oxygen-bearing methylene group at $\delta_{\mathrm{H}} 3.33(\mathrm{~d}, J=11.2 \mathrm{~Hz}, \mathrm{H}-23 \mathrm{a})$ and $3.50(\mathrm{~d}, J=11.2 \mathrm{~Hz}, \mathrm{H}-23 \mathrm{~b})$, and two oxygenated methine groups at $\delta_{\mathrm{H}} 3.82(\mathrm{dd}, J=12.1,4.9 \mathrm{~Hz}, \mathrm{H}-3)$ and $3.27(\mathrm{~d}, J=3.6 \mathrm{~Hz}$, H-19) showed a pentacyclic triterpenoid structure. The ${ }^{13} \mathrm{C}-\mathrm{NMR}$ (Table 1) and DEPT (135) spectra revealed a carboxyl group at $\delta_{C} 182.9$, a keto carbonyl group at $\delta_{C} 215.4$, and two olefinic carbons at $\delta_{C} 125.3$ and 144.0, as well as three oxygen-bearing carbons at $\delta_{C} 73.5(C-3), 82.4(C-19)$, and 65.9 (C-23). Thus, compound 4 was assigned as an olean-type triterpenoid. The NMR data of 4 were closely related to those of the known compound, 3 $\beta$,23-dihydroxy-1-oxo-olean-12-en-28-oic acid [24], except for an additional hydroxyl group. 2D NMR experiments further confirmed the structure of 4. In the HMBC spectrum (Figure 3), the olean-type skeleton was confirmed mainly by correlations 
from $\mathrm{H}_{3}-29$ and $\mathrm{H}_{3}-30$ to $\mathrm{C}-19, \mathrm{C}-20$, and $\mathrm{C}-21$, from $\mathrm{H}_{3}-27$ to $\mathrm{C}-8, \mathrm{C}-13, \mathrm{C}-14$, and C-15, from $\mathrm{H}_{3}-26$ to C-7, C-8, C-9, and C-14, from $\mathrm{H}_{3}-25$ to $\mathrm{C}-1, \mathrm{C}-5, \mathrm{C}-9$, and C-10, from $\mathrm{H}_{3}-24$ to C-3, C-4, C-5, and $\mathrm{C}-23$, and from $\mathrm{H}-18$ to $\mathrm{C}-12$ and $\mathrm{C}-13$. The hydroxyl group at $\mathrm{C}-19$ was verified by the HMBC correlations from $\mathrm{H}-19\left(\delta_{\mathrm{H}} 3.27\right)$ to $\mathrm{C}-13\left(\delta_{\mathrm{C}} 144.0\right)$, and $\mathrm{C}-17\left(\delta_{\mathrm{C}} 47.0\right)$. The configuration was determined by NOESY correlations of H-3/H-23b, H-3/H-5, H-5/H-9, and H-9/ $\mathrm{H}_{3}-27$ for the $\alpha$-oriented hydrogens. Meanwhile, the key $\beta$-oriented hydrogens were identified by NOESY correlations of $\mathrm{H}_{3}-24 / \mathrm{H}_{3}-25, \mathrm{H}_{3}-25 / \mathrm{H}_{3}-26, \mathrm{H}-12 / \mathrm{H}-18$, and $\mathrm{H}-18 / \mathrm{H}_{3}-30$ (Figure 3). The configuration of the hydroxyl group at C-19 was deduced to be $\alpha$-oriented on the basis of observed NOE correlations between $\mathrm{H}-18$ and $\mathrm{H}-19$, and between $\mathrm{H}-19$ and $\mathrm{H}_{3}-30$. Accordingly, compound 4 was deduced as $3 \beta, 19 \alpha, 23-$ trihydroxy-1-oxo-olean-12-en-28-oic acid.
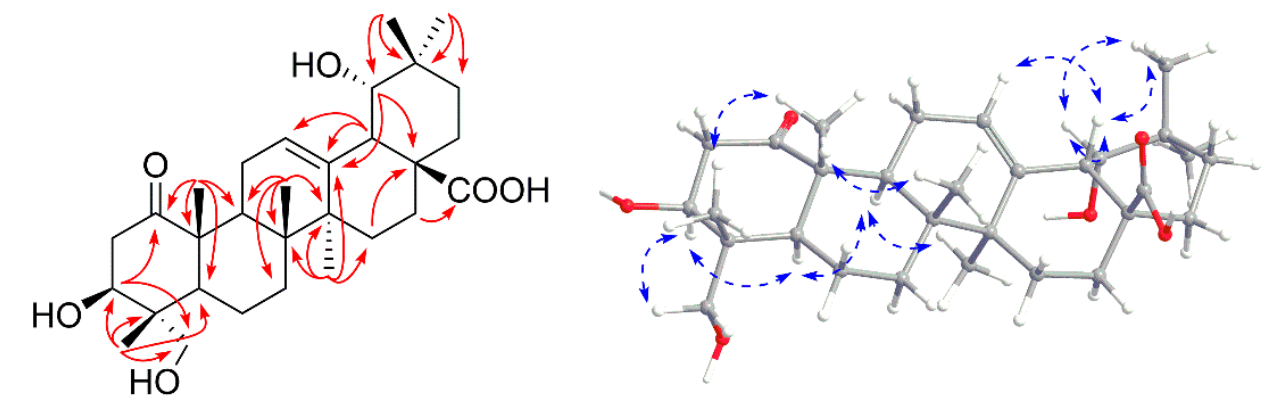

Figure 3. Key HMBC (red arrows) and NOESY (blue dotted double arrows) correlations of 4.

By comparing their NMR data with those reported in the literatures, the eleven known compounds (Table S1) were identified asarjunolic acid (5) [25], cyclocaric acid B (6) [26], $1 \alpha$, 3 $\beta$-dihydroxy-olean12-en-28-oic acid (7) [27], punicaone (8) [28], olean-12-en-1 $\beta, 3 \beta, 28$-triol (9) [29], ursolic acid (10) [30], asiatic acid (11) [31], cyclocarioside K (12) [20], cyclocarioside H (13) [14], cyclocariosideI (14) [32], and cyclocarioside B (15) [33], respectively.

\subsection{Glucose Uptake Assay}

Herein, the fully differentiated 3T3-L1 adipocytes and C2C12 myotubes were used to evaluate the insulin sensitizing effects of the compounds 1-15, using 2-(N-(7-nitrobenz-2-oxa-1,3-diazol-4-yl) amino)-2-deoxyglucose (2-NBDG) uptake assay. Firstly, cell viability was determined using 3-(4,5dimethylthiazol-2-yl)-2,5-diphenyltetrazolium bromide (MTT) assay. The cell viability above $90 \%$ were considered as non-cytotoxicity. As shown in Table S2, the maximum safe dosages for most compounds were $10 \mu \mathrm{M}$, except compounds 2, 3 and $13(2 \mu \mathrm{M})$, in both 3T3-L1 adipocytes and C2C12 myotubes. Under the maximum safe dosages, compounds $\mathbf{1}$ and $\mathbf{5}$ significantly enhanced insulin-stimulated glucose uptake in C2C12 myotubes; and compounds 1, 4, 5, 11, 14 and 15 remarkably promoted insulin-stimulated glucose uptake in 3T3-L1 adipocytes (Figure 4). Among them, compound 1 showed the most potent insulin sensitizing effect, increasing around $18 \%$ and $46 \%$ glucose uptake in $\mathrm{C} 2 \mathrm{C} 12$ myotubes and 3T3-L1 adipocytes, respectively. Resveratrol (RSV, $5 \mu \mathrm{M}$ ) was used as a positive control, which increased about 29\% and 53\% glucose uptake in C2C12 myotubes and 3T3-L1 adipocytes, respectively (Figure 4). The existence of 3-hydroxyl and 23-hydroxymethyl groups is important for the activities of the pentacyclic triterpenoids. 


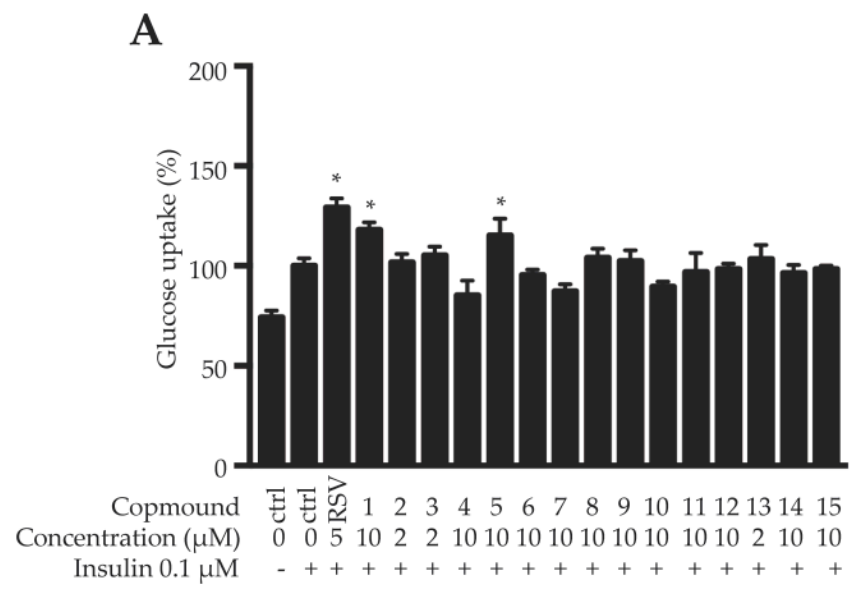

B

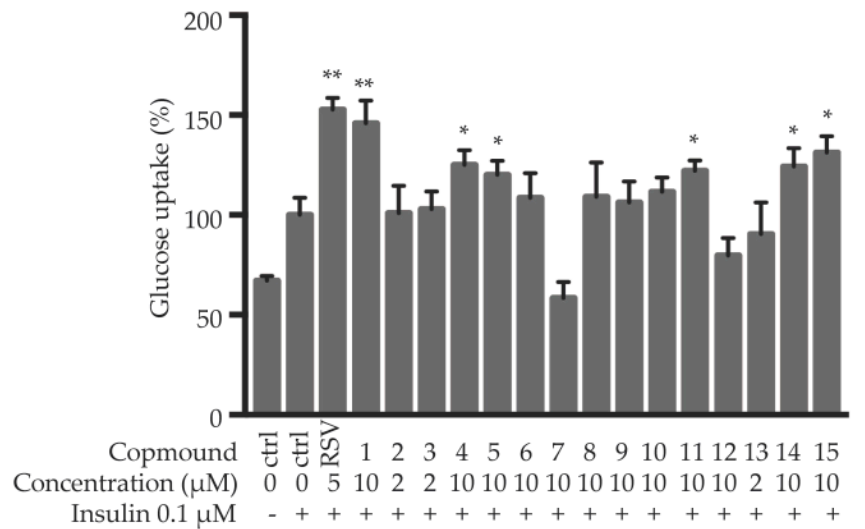

Figure 4. Glucose uptake of the compounds in C2C12 myotubes (A) and 3T3-L1 adipocytes (B). Data are shown as mean $\pm \mathrm{SD}, n=6 .{ }^{*} p<0.05,{ }^{* *} p<0.01$, compound vs. insulin.

2.3. Compound 1 Enhances Insulin Sensitivity in 3T3-L1 Adipocytes through Activating AMP-Activated Protein Kinase (AMPK)-p38 Pathway

Compound 1 didn't show obvious cytotoxicity in 3T3-L1 adipocytes up to $10 \mu \mathrm{M}$ (Figure 5A). As shown in Figure 5B, compound $\mathbf{1}$ increased insulin-stimulated glucose uptake in 3T3-L1 adipocytes in a dose-dependent manner. Next, the key proteins in the insulin signaling pathway were analyzed. As shown in Figure 5C, insulin increased the phosphorylation of IRS-1, Akt, and glycogen synthase kinase $3 \beta$ (GSK-3 $\beta$ ), and compound 1 further enhanced the phosphorylation of these proteins. These results indicated that compound 1 enhances insulin sensitivity and promotes glucose uptake by activating the insulin signaling pathway. 
A

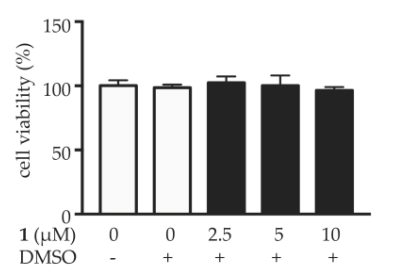

C

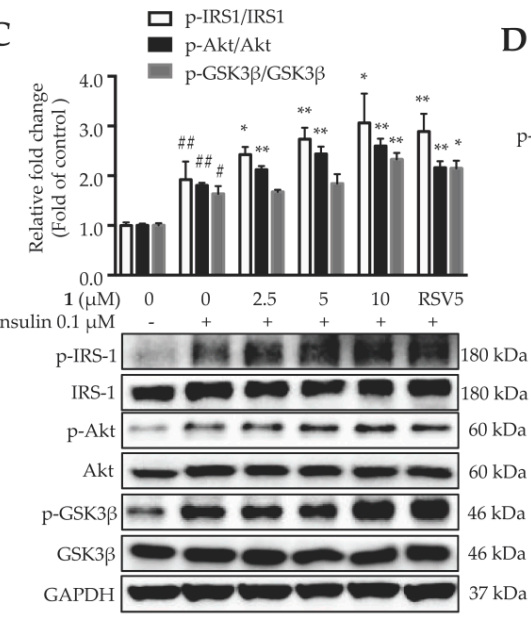

B

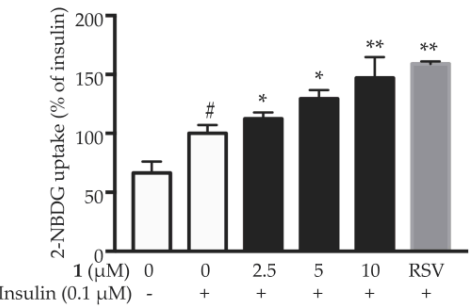

D

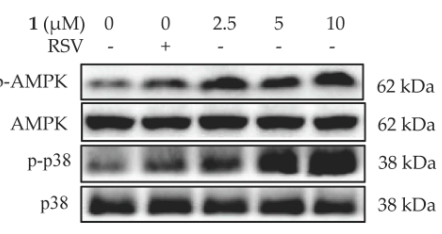

Figure 5. Compound 1 enhances insulin sensitivity in 3T3-L1 adipocytes through activating AMPK-p38 pathway. (A) Cell viability of mature 3T3-L1 adipocytes when treated with different concentrations of compound 1 for $24 \mathrm{~h}$. (B) Compound 1 promotes insulin-stimulated glucose uptake in 3T3-L1 adipocytes. (C) Compound $\mathbf{1}$ activates the proteins in insulin signaling pathway, including IRS-1, Akt and GSK-3 $\beta$. (D) Compound 1 increases the phosphorylation of AMPK and p38MAPK. Data are shown as mean $\pm \mathrm{SD}, n=6 .{ }^{\#} p<0.05,{ }^{\# \#} p<0.01$, vehicle vs. insulin. ${ }^{*} p<0.05,{ }^{* *} p<0.01$, compound 1 vs. DMSO.

Previous reports have revealed that triterpenoids possess hypoglycemic effects through modulating insulin sensitivity in adipose, muscle or liver, and/or insulin secretion in pancreas. Ursolic acid (10), a pentacyclic triterpenoid from many different plants, promotes glucose uptake in adipocytes through enhancing PI3K level and glucose transporter 4 (GLUT4) translocation [7]. Corosolic acid, which is rich in Banaba (Lagerstroemia speciosa) leaf, actives insulin signaling pathway via transmitting the signals to PI3K/Akt as well as extracellular regulated protein kinases (ERK) pathways [34,35]. Moreover, eburicoic acid, a triterpenoid from Antrodia camphorata, displays antidiabetic and hypolipidemic properties in HFD-fed mice through activating AMPK [36].

AMPK, the energy-sensing enzyme, plays a central role in regulating glucose metabolism, which is positively correlated with insulin sensitivity in different tissues [37,38]. P38 mitogen-activated protein kinase (MAPK) exhibits wide-spectrum roles in controlling energy metabolism of adipose tissues [39]. P38 is a downstream component of the AMPK signaling pathway and is essential for insulin stimulated glucose uptake in adipocytes [40]. Several natural compounds are able to increase glucose uptake and improve hyperglycemia through activating AMPK-p38 pathway, including capsaicin [41], curcumin [42] and berberine [43]. Compound 1 increased the phosphorylation of AMPK and its downstream signal p38 in 3T3-L1 adipocytes, in a dose-dependent manner (Figure 5D). These results suggested that compound 1 might activate AMPK and p38 MAPK, to enhance insulin-stimulated glucose uptake in adipocytes.

Most triterpenoids are difficult to permeate through cell membranes. However, chronic intake of triterpene-rich extracts increases their bioavailability and accumulation in circulation and tissues [44]. Cyclodextrins was also reported to improve the bioavailability of triterpenoids [45]. The poor bioavailability of triterpenoids seriously affected their clinical efficacies and limited their 
applications [46]. To elicit their desired pharmacological effect, enzymatic or chemical transformation can be applied [47]. The carriers such as poly-drug conjugates, micelles, nanoparticles, and liposomes might be used to improve drug delivery efficiency [48,49].

\section{Materials and Methods}

\subsection{General Experimental Procedures}

Optical rotations were acquired in $\mathrm{MeOH}$ using a p-1010 polarimeter (Jasco, Easton, MD, USA). Infrared spectra were measured on an Avatar 370 FT-IR spectrometer (Nicolet, Carlsbad, CA, USA) with $\mathrm{KBr}$ disks. HRESIMS were acquired on a $\mathrm{LCQ}^{\mathrm{DECA}} \mathrm{XP}$ instrument (Finnigan, San Jose, CA, USA) and a Q-TOF 1290 LC/6224 MS system (Agilent, Santa Clara, CA, USA). NMR spectra were recorded on an AVANCE III $500 \mathrm{MHz}$ spectrometer (Bruker, Zürich, Switzerland) with tetramethylsilane(TMS) as the internal standard. Silica gel (200-300 mesh, Qingdao Haiyang Chemical Co., Ltd., Qingdao, China), MCI gel (75-150 $\mu \mathrm{m}$, Mitsubishi Chemical Industries Ltd., Tokyo, Japan), D-101 macroporous resin (Chemical Plant of Nankai University, Tianjin, People's Republic of China), $C_{18}$ reverse-phased silica gel (40-75 $\mu \mathrm{m}$, Fuji, Kasugai, Japan), and Sephadex LH-20 gel (Amersham Pharmacia Biotech., Piscataway, NJ, USA) were performed on column chromatography. Precoated silica gel GF254 plates (Qingdao Haiyang Chemical Co., Ltd., Qingdao, China) were used for TLC. D-Quinovose and L-arabinose were purchased from Nantong Feiyu Biological Technology Co., Ltd. (Nantong, Jiangsu, China). All solvents were of analytical grade (Tianjin Yongda Chemical Reagent Co., Ltd., Tianjin, China).

\subsection{Plant Material}

The leaves of Cyclocarya paliurus (Batalin) Iljinsk. (Juglandaceae) were collected in Wencheng County, Wenzhou City, Zhejiang Province, China, in April 2016, and authenticated by one of the authors Jian-Xia Mo. A voucher specimen (accession number CP-2016-I) was deposited in the Institute of Modern Chinese Medicine, Zhejiang University (Hangzhou, China).

\subsection{Extraction and Isolation}

The air-dried leaves of $C$. paliurus $(5 \mathrm{~kg})$ were powdered and extracted with $70 \% \mathrm{EtOH}(3 \times 25 \mathrm{~L})$ at room temperature. A crude extract $(831.0 \mathrm{~g})$ was obtained after removal of the solvent under reduced pressure. The extract was then suspended in $\mathrm{H}_{2} \mathrm{O}(2 \mathrm{~L})$ and successively partitioned with petroleum ether, EtOAc, and $n$-BuOH(volume ratio of 1:1) to give three fractions, CPP (129.9 g), CPE (227.2 g), and CPB (136.2 g), respectively. The EtOAc fraction CPE was first subjected to a D-101 macroporous resin column eluted with aqueous $\mathrm{EtOH}$ (30\% to $95 \%$, stepwise) to afford seven subfractions of CPEA-CPEG. CPEC (4.0 g) was separated on a Sephadex LH-20 column $\left(\mathrm{CH}_{2} \mathrm{Cl}_{2}-\mathrm{MeOH}, 1: 1\right)$ to yield three subfractions (CPEC1-CPEC3). CPEC2 (2.3 g) was further chromatographed over a $\mathrm{C}_{18}$ reversed-phase column (from $30 \%$ to $100 \%$ aqueous $\mathrm{MeOH}$ ), followed by a silica gel column $\left(\mathrm{CH}_{2} \mathrm{Cl}_{2}-\mathrm{MeOH}, 40: 1\right)$ to obtain compound $4(7.0 \mathrm{mg})$. CPED $(37.9 \mathrm{~g})$ was purified by an MCI gel column eluted with aqueous $\mathrm{MeOH}(30 \%$ to $100 \%$, stepwise) to give seven subfractions of CPED1-CPED7. CPED2 (5.5 g) was further separated by a $\mathrm{C}_{18}$ reversed-phase silica gel column (from $30 \%$ to $100 \%$ aqueous $\mathrm{MeOH}$ ) to afford five subfractions of CPED2a-CPED2e. CPED2b (1.2 g) was further chromatographed on a silica gel column $\left(\mathrm{CH}_{2} \mathrm{Cl}_{2}-\mathrm{MeOH}, 30: 1\right.$ to 5:1) to afford compounds $13(33.5 \mathrm{mg})$ and $14(51.3 \mathrm{mg})$. CPED2d $(0.7 \mathrm{~g})$ was subjected to a silica gel column $\left(\mathrm{CH}_{2} \mathrm{Cl}_{2}-\mathrm{MeOH}\right.$, 20:1 to 0:1) to give compound $12(42.2 \mathrm{mg})$. Next, CPED3 (6.9 g) was fractionated by a silica gel column $\left(\mathrm{CH}_{2} \mathrm{Cl}_{2}\right.$-acetone, 8:1 to 0:1) and purified by repeated recrystallization to yield compounds 6 (1.6 g) and 5 (1.2 g). Compound $\mathbf{1 1}(50.4 \mathrm{mg})$ was obtained from CPED5 (0.8 g) via a Sephadex LH-20 column $\left(\mathrm{CH}_{2} \mathrm{Cl}_{2}-\mathrm{MeOH}, 1: 1\right)$. CPEE (30.3 g) was subjected to an MCI gel column eluted with aqueous $\mathrm{MeOH}$ (30\% to 100\%, stepwise) to give eight subfractions of CPEE1-CPEE8. CPEE4 (5.3 g) was performed on a $\mathrm{C}_{18}$ reversed-phase silica gel column (from $30 \%$ to $100 \%$ aqueous $\mathrm{MeOH}$ ) to give five subfractions (CPEE4a-CPEE4e). Compound 15 (29.0 mg) was obtained from CPEE4a $(0.9 \mathrm{~g})$ by a silica gel column 
(EtOAc-MeOH, 50:1 to 18:1), and compound 1 (22.0 mg) was from CPEE4b (1.1 g). CPEE4d (1.8 g) was further chromatographed on a silica gel column $\left(\mathrm{CH}_{2} \mathrm{Cl}_{2}-\mathrm{MeOH}, 45: 1\right.$ to 18:1) to yield compounds 3 (21.4 $\mathrm{mg})$ and 2 (23.9 mg). CPEE6 (2.3 g) was passed through a silica gel column $\left(\mathrm{CH}_{2} \mathrm{Cl}_{2}-\mathrm{MeOH}, 60: 1\right.$ to $0: 1)$ to give compounds $8(25.8 \mathrm{mg})$ and $\mathbf{9}(15.5 \mathrm{mg})$. CPEF $(8.4 \mathrm{~g})$ was separated on a silica gel column (petroleum ether-acetone, 15:1 to 0:1) to give seven subfractions of CPEF1-CPEF7. CPEF4 (0.9 g) was purified by a Sephadex LH-20 column $\left(\mathrm{CH}_{2} \mathrm{Cl}_{2}-\mathrm{MeOH}, 1: 1\right)$ to afford compound 10 (132.0 mg). CPEF6 $(0.4 \mathrm{~g})$ was further chromatographed on a silica gel column $\left(\mathrm{CH}_{2} \mathrm{Cl}_{2}\right.$-EtOAc, $16: 1$ to $\left.6: 1\right)$ to obtain compound 7 (35.8 mg).

(20S,24R)-20,24-Epoxy-25-hydroxy-12 $\beta$-( $\alpha$-L-arabinopyranosyloxy)-3,4-seco-dammara-4(28)-en-3-oic acid (1): White amorphous powder; $[\alpha]_{D}^{25}+27.2$ (c 0.09, MeOH); IR (KBr) $v_{\max } 3405,2964,1699,1685,1455,1394$, 1087, 1002, $946 \mathrm{~cm}^{-1} ;{ }^{1} \mathrm{H}$ - and ${ }^{13} \mathrm{C}-\mathrm{NMR}$ data, see Table 1 ; ESIMS (positive) $\mathrm{m} / z 645[\mathrm{M}+\mathrm{Na}]^{+}$; ESIMS (negative) $m / z 621[\mathrm{M}-\mathrm{H}]^{-}$; HRESIMS (positive) $m / z 645.3978[\mathrm{M}+\mathrm{Na}]^{+}$(calcd for $\mathrm{C}_{35} \mathrm{H}_{58} \mathrm{O}_{9} \mathrm{Na}_{\text {, }}$ 645.3979).

(20S,24R)-20,24-Epoxy-25-hydroxy-12 $\beta$-( $\alpha$-L-arabinopyranosyloxy)-3,4-seco-dammara-4(28)-en-3-oic acid methyl ester (2): White amorphous powder; $[\alpha]_{D}^{25}+24.9$ (c 0.10, MeOH); IR (KBr) $v_{\max } 3418,2963$, $1721,1634,1454,1377,1087,1001,946,893 \mathrm{~cm}^{-1} ;{ }^{1} \mathrm{H}$ - and ${ }^{13} \mathrm{C}-\mathrm{NMR}$ data, see Table 1; ESIMS (positive) $m / z 637[\mathrm{M}+\mathrm{H}]^{+}$; ESIMS (negative) $m / z 681\left[\mathrm{M}+\mathrm{HCOO}^{-}{ }\right.$; HRESIMS (positive) $m / z 659.4127$ $[\mathrm{M}+\mathrm{Na}]^{+}$(calcd for $\left.\mathrm{C}_{36} \mathrm{H}_{60} \mathrm{O}_{9} \mathrm{Na}, 659.4135\right)$.

(20S,24R)-20,24-Epoxy-25-hydroxy-12 $\beta$-( $\beta$-D-quinovopyranosyloxy)-3,4-seco-dammara-4(28)-en-3-oic acid methyl ester (3): White amorphous powder; $[\alpha]_{D}^{25}+17.5$ (c 0.08, MeOH); IR (KBr) $v_{\max } 3416,2965,1715$, 1635, 1455, 1394, 1166, 1067, $893 \mathrm{~cm}^{-1} ;{ }^{1} \mathrm{H}$ - and ${ }^{13} \mathrm{C}-\mathrm{NMR}$ data, see Table 1; ESIMS (positive) $\mathrm{m} / z 651$

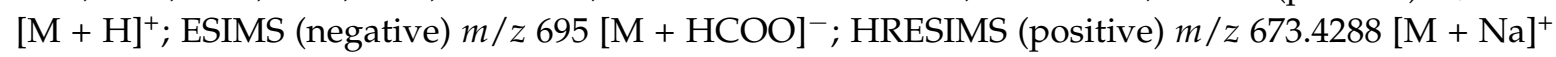
(calcd for $\mathrm{C}_{37} \mathrm{H}_{62} \mathrm{O}_{9} \mathrm{Na}, 673.4292$ ).

$3 \beta, 19 \alpha, 23-T r i h y d r o x y-1-o x o-o l e a n-12-e n-28$-oic acid (4): White amorphous powder; $[\alpha]_{D}^{25}+62.2$ (c 0.10 , $\mathrm{MeOH}) ; \mathrm{IR}(\mathrm{KBr}) v_{\max } 3414,2946,1695,1463,1385,1040,955 \mathrm{~cm}^{-1} ;{ }^{1} \mathrm{H}$ - and ${ }^{13} \mathrm{C}-\mathrm{NMR}$ data, see Table 1 ; ESIMS (positive) $m / z 525[\mathrm{M}+\mathrm{Na}]^{+} ;$ESIMS (negative) $m / z 537[\mathrm{M}+\mathrm{Cl}]^{-}$; HRESIMS (positive) $m / z$ $525.3185[\mathrm{M}+\mathrm{Na}]^{+}$(calcd for $\mathrm{C}_{30} \mathrm{H}_{46} \mathrm{O}_{6} \mathrm{Na}, 525.3192$ ).

\subsection{Acid Hydrolysis of Compounds 1-3}

The configuration of sugar moieties was established according to the published method with some modifications [22,50]. Compounds 1-3 (5.0 mg of each)were refluxed with $10 \% \mathrm{HCl}$ in $\mathrm{EtOH}$ $(10 \mathrm{~mL})$ for $6 \mathrm{~h}$, respectively. Each reaction mixture was diluted with $\mathrm{H}_{2} \mathrm{O}$ and extracted with EtOAc $(3 \times 15 \mathrm{~mL})$. After neutralizing with $\mathrm{Na}_{2} \mathrm{CO}_{3}$, the presence of L-arabinose inthe aqueous layer for $\mathbf{1 , 2}$ was detected by co-TLC $\left(\mathrm{CH}_{2} \mathrm{Cl}_{2}-\mathrm{MeOH}-\mathrm{H}_{2} \mathrm{O}, 12: 8: 1, R_{f}=0.65\right)$ with an authentic sample, and that of D-quinovose for 3 was also confirmed by co-TLC $\left(\mathrm{CH}_{2} \mathrm{Cl}_{2}-\mathrm{MeOH}-\mathrm{H}_{2} \mathrm{O}, 12: 8: 1, R_{f}=0.55\right)$ with an authentic sample.

\subsection{Reagents}

All the isolates and RSV were dissolved in DMSO (less than 0.1\% in the cell-based assays). Fetal bovine serum (FBS), calf serum (CS), horse serum (HS), penicillin-streptomycin (P/S), Dulbecco's modified Eagle's medium (DMEM), and phosphate-buffered saline (PBS) powder were purchased from Life Technologies (Grand Island, NY, USA). All the chemicals (analytical grade) were obtained from Sigma-Aldrich (St. Louis, MO, USA), except those otherwise specified. Antibody details were as follows: p-p38 (sc-166182), p38 (sc-81621), Akt (sc-8312), p-Akt (sc-7985), AMPK (sc-25792), p-AMPK (sc-33524), p-IRS1 (sc-17196) and GAPDH (sc-25778) were purchased from Santa Cruz Biotechnology, Inc. (Santa Cruz, CA, USA). p-GSK3ß (\#9323), GSK3 $\beta$ (\#12456) and IRS1 (\#2382) were from Cell Signaling (Danvers, MA, USA). 


\subsection{Cell Culture and Treatment}

Mouse C2C12 myoblasts and 3T3-L1 preadipocytes were obtained from ATCC (Manassas, VA, USA). C2C12 cells were cultured in DMEM supplied with 10\% FBS and 1\% P/S. After 70-80\% confluence, the $\mathrm{C} 2 \mathrm{C} 12$ cells were incubated with DMEM containing 1\% P/S and 2\% heat-inactivated HS for 4 days, to induce differentiation. Medium was changed every other day. The fully differentiated cells were treated with the different concentration of compounds for $24 \mathrm{~h}$.

3T3-L1 preadipocytes were cultured in DMEM supplied with 10\% CS and 1\% P/S.2 Days post confluence, the cells were incubated with DMEM supplied with 10\% FBS and DMI ( $1 \mu \mathrm{M}$ dexamethasone, $0.5 \mathrm{mM}$ 3-isobutyl-1-methylxanthine, and $5 \mu \mathrm{g} / \mathrm{mL}$ insulin) for 2 days. Subsequently, cells were maintained in DMEM supplied with 10\% FBS and $5 \mu \mathrm{g} / \mathrm{mL}$ insulin for 6 days, and medium was refreshed every other day. On day 8 , fully differentiated adipocytes were treated with compounds at indicated concentrations for $24 \mathrm{~h}$.

\subsection{Cell Viability Assay}

Cell viability was determined by the 3-(4,5-dimethylthiazol-2-yl)-2,5-diphenyltetrazolium bromide (MTT) assay (Sigma-Aldrich) as described previously [51]. Briefly, cells were seeded in 96-well plates at a density of $5 \times 10^{4}$ cells/well. 3T3-L1 adipocytes and C2C12 myotubes were treated with compounds at indicated concentrations for $24 \mathrm{~h}$, respectively. Subsequently, cell viability was determined by incubation with $1 \mathrm{mg} / \mathrm{mL}$ MTT solution in DMEM at $37{ }^{\circ} \mathrm{C}$ for $4 \mathrm{~h}$, followed by dissolving the violet-formazan crystals with $100 \mu \mathrm{L}$ DMSO. The absorbance at $570 \mathrm{~nm}$ was measured by a SpectraMax M5 microplate reader (Molecular Devices, San Jose, CA, USA). Cell viability of each group was expressed as a percentage of the control group treated with DMSO.

\subsection{Glucose Uptake Assay}

Glucose uptake assay was followed as previous study [52]. Fully differentiated 3T3-L1 adipocytes and C2C12 myotubes were treated with compounds at indicated concentrations for $24 \mathrm{~h}$. After washed with Krebs-Ringer's phosphate (KRP) buffer (20 mM HEPES, $137 \mathrm{mM} \mathrm{NaCl}, 4.7 \mathrm{mM} \mathrm{KCl,} 1.2 \mathrm{mM}$ $\mathrm{MgSO}_{4}, 1.2 \mathrm{mM} \mathrm{KH} \mathrm{PO}_{4}, 2.5 \mathrm{mM} \mathrm{CaCl}_{2}$, and $2 \mathrm{mM}$ pyruvate; $\mathrm{pH} 7.4$ ), cells were incubated in KRP buffer with $0.2 \%$ bovine serum albumin for $3 \mathrm{~h}$. Next, cells were incubated with KRP buffer with $0.1 \mu \mathrm{M}$ insulin for another $30 \mathrm{~min}$, to stimulate glucose uptake. Cells were incubated for another $30 \mathrm{~min}$ in KRP containing $100 \mu \mathrm{M}$ 2-NBDG after washed with KRP buffer once. The intracellular content of 2-NBDG was determined at an excitation wavelength of $475 \mathrm{~nm}$ and an emission wavelength of $550 \mathrm{~nm}$ using a SpectraMax M5 microplate reader. Finally, glucose uptake was normalized with protein content.

\subsection{Western Blot Analysis}

Western blot analysis was followed as previous study [53]. After washed twice with ice-cold PBS, 3T3-L1 adipocytes were lysed with cold RIPA buffercontaining freshly added phosphatase inhibitor cocktails and phenylmethylsulfonyl fluoride (PMSF), by incubating on ice for $30 \mathrm{~min}$. The supernatants were collected after centrifuging the cell lysates at $17,400 \times g$ for $20 \mathrm{~min}$ at $4^{\circ} \mathrm{C}$. BCA protein assay kit (Life Technologies, Grand Island, NY, USA) was used to quantified the protein concentration of each sample. Equal amount of proteins $(30 \mu \mathrm{g})$ were separated by $8-10 \%$ sodium dodecyl sulfate polyacrylamide gel electrophoresis (SDS-PAGE) and transferred to polyvinylidene difluoride (PVDF) membranes (Bio-Rad Laboratories, Inc., Hercules, CA, USA). The membranes were blocked with 5\% nonfat milk in TBST buffer $(100 \mathrm{mM} \mathrm{NaCl}, 10 \mathrm{mM}$ Tris-HCl, pH 7.5 and $0.1 \%$ Tween-20) for $1 \mathrm{~h}$ at room temperature and then incubated with specific primary antibodies in TBST buffer overnight at $4{ }^{\circ} \mathrm{C}$. After washing with TBST buffer thrice, the membranes were incubated with a horseradish peroxidase conjugated secondary antibody for $2 \mathrm{~h}$ at room temperature. The specific signals were developed 
using a SuperSignal West Femto Maximum Sensitivity Substrate kit (Thermo, Rockford, IL, USA), and visualized using the ChemiDoc MP Imaging System.

\subsection{Statistical Analysis}

Statistical analyses were performed by Graphpad Prism 6 (GraphPad Software, San Diego, CA, USA). The data were expressed as mean \pm S.D. based on at least three independent experiments. Statistical differences were accepted as significant at $p$-values less than 0.05 , analyzing by one-way ANOVA with Dunnett's test in multiple comparison.

\section{Conclusions}

Phytochemical investigation on the leaves of C. paliurus led to the isolation of 15 triterpenoids including three undescribed seco-dammarane triterpenoid glycosides 1-3, one undescribed pentacyclic triterpenic acid 4, and eleven known analogues. Among them, the three seco-dammarane triterpenoid glycosides 1-3 possessing 20,24-epoxy linkages are rarely found among the seco-dammarane triterpenoids from this genus. Several triterpenoids were found to enhance insulin-stimulated glucose uptake in both C2C12 myotubes and 3T3-L1 adipocytes. The insulin sensitizing effect of triterpenoids from C. paliurus was more potent in adipocytes than that in myotubes. Compound $\mathbf{1}$ enhances insulin sensitivity in adipocytes through activating AMPK-p38 pathway (Figure 6). Collectively, triterpenoids from C. paliurus could be developed as insulin sensitizers, which might have therapeutic potential for insulin resistance and hyperglycemia.

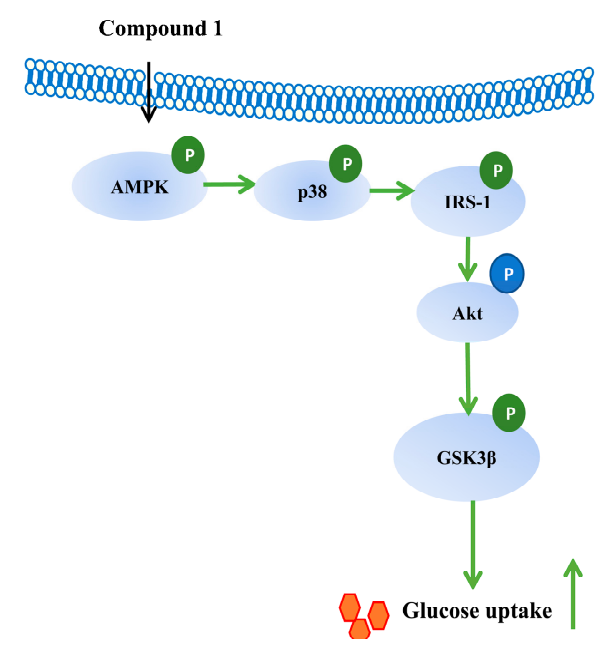

Figure 6. The mechanism of action of compound 1.

Supplementary Materials: The following are available online. Figure S1-S40: 1D and 2D NMR, MS, and IR spectra of compounds 1-4; Table S1: Structures of known compounds; Table S2: Cytotoxicity of the isolates in C2C12 myotubes and 3T3-L1 adipocytes.

Author Contributions: Z.-J.F. performed the isolation and structure elucidation of the compounds. J.-X.M. identified the plant materials. J.-M.W., Y.-J.W. and C.-X.Z. contributed in the interpretation of the spectra and also part of the preparation of the manuscript. S.-N.S. and L.-G.L. accomplished the pharmacological study part and prepared the corresponding part of manuscript. L.-S.G. planned, designed and organized the whole research of this study. All authors approved the final version of the manuscript.

Funding: This research was funded by Zhejiang Provincial Natural Science Foundation of China (LR17H300001), National Natural Science Foundation of China (81872756, 81473103), Key Technology R\&D Program of Zhejiang Province (2018C02034), and Science and Technology Development Fund, Macao S.A.R (FDCT 102/2017/A).

Acknowledgments: We thank Jina Du and Wencheng Quanshan Chinese Medicinal Materials Planting Co., Ltd. for providing us the plant material. The authors acknowledge all contributors for their valuable time and commitment tothe study.

Conflicts of Interest: The authors declare no conflicts of interest. 


\section{References}

1. Mahomoodally, M.F.; Mootoosamy, A.; Wambugu, S. Traditional therapies used to manage diabetes and related complications in mauritius: A comparative ethnoreligious study. J. Evid.-Based Complement. Altern. Med. 2016, 2016, 4523828. [CrossRef] [PubMed]

2. Maruthur, N.M.; Tseng, E.; Hutfless, S.; Wilson, L.M.; Suarez-Cuervo, C.; Berger, Z.; Chu, Y.; Iyoha, E.; Segal, J.B.; Bolen, S. Diabetes medications as monotherapy or metformin-based combination therapy for Type 2 Diabetes: A systematic review and meta-analysis. Ann. Intern. Med. 2016, 164, 740-751. [CrossRef] [PubMed]

3. Katiyar, D.; Singh, V.; Gilani, S.J.; Goel, R.; Grover, P.; Vats, A. Hypoglycemic herbs and their polyherbal formulations: A comprehensive review. Med. Chem. Res. 2015, 24, 1-21. [CrossRef]

4. Han, J.H.; Tuan, N.Q.; Park, M.H.; Quan, K.T.; Oh, J.; Heo, K.S.; Na, M.; Myung, C.S. Cucurbitane triterpenoids from the fruits of Momordica Charantia improve insulin sensitivity and glucose homeostasis in streptozotocin-induced diabetic mice. Mol. Nutr. Food Res. 2018, 62, 1700769. [CrossRef] [PubMed]

5. Sudirman, S.; Hsu, Y.H.; Kong, Z.L. The amelioration effects of nanoencapsulated triterpenoids from petri dish-cultured Antrodia cinnamomea on reproductive function of diabetic male rats. Int. J. Chem. Biol. Eng. 2018, 12, 5059-5073. [CrossRef] [PubMed]

6. Xu, J.; Liu, T.; Li, Y.; Yuan, C.; Ma, H.; Seeram, N.P.; Liu, F.; Mu, Y.; Huang, X.; Li, L. Hypoglycemic and hypolipidemic effects of triterpenoid-enriched Jamun (Eugenia jambolana Lam.) fruit extract in streptozotocin-induced type 1 diabetic mice. Food Funct. 2018, 9, 3330-3337. [CrossRef] [PubMed]

7. Rao, V.S.; de Melo, C.L.; Queiroz, M.G.R.; Lemos, T.L.G.; Menezes, D.B.; Melo, T.S.; Santos, F.A. Ursolic acid, a pentacyclic triterpene from Sambucus australis, prevents abdominal adiposity in mice fed a high-fat diet. J. Med. Food 2011, 14, 1375-1382. [CrossRef]

8. Kazmi, I.; Rahman, M.; Afzal, M.; Gupta, G.; Saleem, S.; Afzal, O.; Shaharyar, M.A.; Nautiyal, U.; Ahmed, S.; Anwar, F. Anti-diabetic potential of ursolic acid stearoyl glucoside: A new triterpenic gycosidic ester from Lantana camara. Fitoterapia 2012, 83, 142-146. [CrossRef]

9. Editor Committee for Flora of China of Chinese Academy of Science. Flora of China; Science Publishing House: Beijing, China, 1979; Volume 21, pp. 18-19.

10. The Editorial Committee of the Administration Bureau of Traditional Chinese Medicine. Chinese Materia Medica (ZhonghuaBencao); Shanghai Science and Technology Publishing House: Shanghai, China, 1999; Volume 2, pp. 370-371.

11. Li, S.; Li, J.; Guan, X.L.; Li, J.; Deng, S.P.; Li, L.Q.; Tang, M.T.; Huang, J.G.; Chen, Z.Z.; Yang, R.Y. Hypoglycemic effects and constituents of the barks of Cyclocarya paliurus and their inhibiting activities to glucosidase and glycogen phosphorylase. Fitoterapia 2011, 82, 1081-1085. [CrossRef]

12. Xie, J.H.; Xie, M.Y.; Nie, S.P.; Shen, M.Y.; Wang, Y.X.; Li, C. Isolation, chemical composition and antioxidant activities of a water-soluble polysaccharide from Cyclocarya paliurus (Batal.) Iljinskaja. Food Chem. 2010, 119, 1626-1632. [CrossRef]

13. Zhang, J.; Shen, Q.; Lu, J.C.; Li, J.Y.; Liu, W.Y.; Yang, J.J.; Li, J.; Xiao, K. Phenolic compounds from the leaves of Cyclocarya paliurus (Batal.) Ijinskaja and their inhibitory activity against PTP1B. Food Chem. 2010, 119, 1491-1496. [CrossRef]

14. Li, S.; Cui, B.S.; Liu, Q.; Tang, L.; Yang, Y.C.; Jin, X.J.; Shen, Z.F. New triterpenoids from the leaves of Cyclocarya paliurus. Planta Med. 2012, 78, 290-296. [CrossRef] [PubMed]

15. Wang, Q.; Jiang, C.; Fang, S.; Wang, J.; Ji, Y.; Shang, X.; Ni, Y.; Yin, Z.; Zhang, J. Antihyperglycemic, antihyperlipidemic and antioxidant effects of ethanol and aqueous extracts of Cyclocarya paliurus leaves in type 2 diabetic rats. J. Ethnopharmacol. 2013, 150, 1119-1127. [CrossRef] [PubMed]

16. Jiang, C.; Yao, N.; Wang, Q.; Zhang, J.; Sun, Y.; Xiao, N.; Liu, K.; Huang, F.; Fang, S.; Shang, X.; et al. Cyclocarya paliurus extract modulates adipokine expression and improves insulin sensitivity by inhibition of inflammation in mice. J. Ethnopharmacol. 2014, 153, 344-351. [CrossRef] [PubMed]

17. Wu, Z.F.; Meng, F.C.; Cao, L.J.; Jiang, C.H.; Zhao, M.G.; Shang, X.L.; Fang, S.Z.; Ye, W.C.; Zhang, Q.W.; Zhang, J.; et al. Triterpenoids from Cyclocarya paliurus and their inhibitory effect on the secretion of apoliprotein B48 in Caco-2 cells. Phytochemistry 2017, 142, 76-84. [CrossRef] [PubMed] 
18. Yang, H.M.; Yin, Z.Q.; Zhao, M.G.; Jiang, C.H.; Zhang, J.; Pan, K. Pentacyclic triterpenoids from Cyclocarya paliurus and their antioxidant activities in FFA-induced HepG2 steatosis cells. Phytochemistry 2018, 151, 119-127. [CrossRef]

19. Zhu, K.N.; Jiang, C.H.; Tian, Y.S.; Xiao, N.; Wu, Z.F.; Ma, Y.L.; Lin, Z.; Fang, S.Z.; Shang, X.L.; Liu, K.; et al. Two triterpeniods from Cyclocarya paliurus (Batal) Iljinsk (Juglandaceae) promote glucose uptake in 3T3-L1 adipocytes: The relationship to AMPK activation. Phytomedicine 2015, 22, 837-846. [CrossRef]

20. Cui, B.S.; Li, S. New triterpenoid saponins from the leaves of Cyclocarya paliurus. Chin. Chem. Lett. 2015, 26, 585-589. [CrossRef]

21. Wang, Y.R.; Cui, B.S.; Han, S.W.; Li, S. New dammarane triterpenoid saponins from the leaves of Cyclocarya paliurus. J. Asian Nat. Prod. Res. 2018. [CrossRef]

22. Ju, J.H.; Liu, D.; Lin, G.; Xu, X.D.; Han, B.; Yang, J.S.; Tu, G.Z.; Ma, L.B. Beesiosides A-F, six new cycloartane triterpene glycosides from Beesia calthaefolia. J. Nat. Prod. 2002, 65, 42-47. [CrossRef]

23. Chen, Y.J.; Na, L.; Fan, J.; Zhao, J.; Hussain, N.; Jian, Y.Q.; Yuan, H.; Li, B.; Liu, B.; Choudhary, M.I.; et al. Seco-dammarane triterpenoids from the leaves of Cyclocarya paliurus. Phytochemistry 2018, 145, 85-92. [CrossRef] [PubMed]

24. Okada, Y.; Omae, A.; Okuyama, T. A new triterpenoid isolated from Lagerstronemia speciosa (L.) PERS. Chem. Pharm. Bull. 2003, 51, 452-454. [CrossRef] [PubMed]

25. Jayasinghe, L.; Percy Wannigama, G.; Macleod, J.K. Triterpenoids from Anamirta cocculus. Phytochemistry 1993, 34, 1111-1116.

26. Cui, B.S.; Li, S. Chemical constituents from leaves of Cyclocarya paliurus. Zhongcaoyao 2012, 43, $2132-2136$.

27. Chen, J.; Chen, B.; Tian, J.; Wu, F.E. Two new pentacyclic triterpenes from Sabia parviflora. Chin. Chem. Lett. 2002, 13, 345-348.

28. Jiang, H.Z.; Ma, Q.Y.; Fan, H.J.; Liang, W.J.; Huang, S.Z.; Dai, H.F.; Wang, P.C.; Ma, X.F.; Zhao, Y.X. Fatty acid synthase inhibitors isolated from Punica granatum L. J. Braz. Chem. Soc. 2012, 23, 889-893. [CrossRef]

29. Murakami, T.; Nagasawa, M.; Itokawa, H.; Tachi, Y.; Tanaka, K. The Structure of a new triterpene, momordic acid, obtained from Momordica cochinchinensis. Tetrahedron Lett. 1966, 42, 5137-5140. [CrossRef]

30. Sang, S.; Lapsley, K.; Rosen, R.T.; Ho, C.T. New prenylated benzoic acid and other constituents from almond hulls (Prunus amygdalus Batsch). J. Agric. Food Chem. 2002, 50, 607-609. [CrossRef]

31. Aguirre, M.C.; Delporte, C.; Backhouse, N.; Erazo, S.; Letelier, M.E.; Cassels, B.K.; Silva, X.; Alegría, S.; Negrete, R. Topical anti-inflammatory activity of $2 \alpha$-hydroxy pentacyclic triterpene acids from the leaves of Ugnimolinae. Bioorg. Med. Chem. 2006, 14, 5673-5677. [CrossRef]

32. Ren, S.G.; Xu, C.R.; Li, L.N. Studies on the sweet principles from the leaves of Cyclocarya paliurus. Acta Pharm. Sin. 1995, 30, 757-761.

33. Jiang, Z.Y.; Zhang, X.M.; Zhou, J.; Qiu, S.X.; Chen, J.J. Two new triterpenoid glycosides from Cyclocarya paliurus. J. Asian Nat. Prod. Res. 2006, 8, 93-98. [CrossRef] [PubMed]

34. Miura, T.; Takagi, S.; Ishida, T. Management of diabetes and its complications with banaba (Lagerstroemia speciosa L.) and corosolic acid. J. Evid.-Based Complement. Altern. Med. 2012, 871495.

35. Shi, L.; Zhang, W.; Zhou, Y.Y.; Zhang, Y.N.; Li, J.Y.; Hu, L.H.; Li, J. Corosolic acid stimulates glucose uptake via enhancing insulin receptor phosphorylation. Eur. J. Pharmacol. 2008, 584, 21-29. [CrossRef] [PubMed]

36. Lin, C.H.; Kuo, Y.H.; Shih, C.C. Eburicoicacid, a triterpenoid compound from Antrodia camphorata, displays antidiabetic and antihyperlipidemic effects in palmitate-treated $\mathrm{C} 2 \mathrm{C} 12$ myotubes and in high-fat diet-fed mice. Int. J. Mol. Sci. 2017, 18, 2314. [CrossRef] [PubMed]

37. Towler, M.C.; Hardie, D.G. AMP-activated protein kinase in metabolic control andinsulin signaling. Circ. Res. 2007, 100, 328-341. [CrossRef] [PubMed]

38. Zachariah Tom, R.; Garcia-Roves, P.M.; Sjögren, R.J.O.; Jiang, L.Q.; Holmström, M.H.; Deshmukh, A.S.; Vieira, E.; Chibalin, A.V.; Björnholm, M.; Zierath, J.R. Effects of AMPK activation on insulin sensitivity and metabolism in leptin-deficient $o b / o b$ mice. Diabetes 2014, 63, 1560-1571. [CrossRef] [PubMed]

39. Xi, X.; Han, J.; Zhang, J.Z. Stimulation of glucose transport by AMP-activated protein kinase via activation of p38 mitogen-activated protein kinase. J. Biol. Chem. 2001, 276, 41029-41034. [CrossRef]

40. Somwar, R.; Koterski, S.; Sweeney, G.; Sciotti, R.; Djuric, S.; Berg, C.; Trevillyan, J.; Scherer, P.E.; Rondinone, C.M.; Klip, A. A dominant-negative p38 MAPK mutant and novel selective inhibitors of p38 MAPK reduce insulin-stimulated glucose uptake in 3T3-L1 adipocytes without affecting GLUT4 translocation. J. Biol. Chem. 2002, 277, 50386-50395. [CrossRef] 
41. Kim, S.H.; Hwang, J.T.; Park, H.S.; Kwon, D.Y.; Kim, M.S. Capsaicin stimulates glucose uptake in C2C12 muscle cells via the reactive oxygen species (ROS)/AMPK/p38 MAPK pathway. Biochem. Biophys. Res. Commun. 2013, 439, 66-70. [CrossRef]

42. Kim, J.H.; Park, J.M.; Kim, E.K.; Lee, J.O.; Lee, S.K.; Jung, J.H.; You, G.Y.; Park, S.H.; Suh, P.G.; Kim, H.S. Curcumin stimulates glucose uptake through AMPK-p38 MAPK pathways in L6 myotube cells. J. Cell.Physiol. 2010, 223, 771-778. [CrossRef]

43. Cheng, Z.; Pang, T.; Gu, M.; Gao, A.H.; Xie, C.M.; Li, J.Y.; Nan, F.J.; Li, J. Berberine-stimulated glucose uptake in L6 myotubes involves both AMPK and p38 MAPK. Biochim. Biophys. Acta 2006, 1760, 1682-1689. [CrossRef] [PubMed]

44. Yin, M.C.; Lin, M.C.; Mong, M.C.; Lin, C.Y. Bioavailability, distribution, and antioxidative effects of selected triterpenes in mice. J. Agric. Food Chem. 2012, 60, 7697-7701. [CrossRef] [PubMed]

45. Cerga, O.; Borcan, F.; Ambrus, R.; Popovici, I. Syntheses of new cyclodextrin complexes with oleanolic and ursolic acids. J. Agroaliment. Process. Technol. 2011, 17, 405-409.

46. Zhou, M.; Zhang, R.H.; Wang, M.; Xu, G.B.; Liao, S.G. Prodrugs of triterpenoids and their derivatives. Eur. J. Med. Chem. 2017, 131, 222-236. [CrossRef] [PubMed]

47. Rautio, J.; Kumpulainen, H.; Heimbach, T.; Oliyai, R.; Oh, D.; Jarvinen, T.; Savolainen, J. Prodrugs: Design and clinical applications. Nat. Rev. Drug Discov. 2008, 7, 255-270. [CrossRef] [PubMed]

48. Deepagan, V.G.; Thambi, T.; Ko, H.; Kang, Y.M.; Park, J.H. Amphiphilic polysialic acid derivatives: Synthesis, characterization, and in-vitro cytotoxicity. J. Nanosci. Nanotechnol. 2013, 13, 7312-7318. [CrossRef]

49. Thambi, T.; Deepagan, V.G.; Ko, H.; Lee, D.S.; Park, J.H. Bioreducible polymersomes for intracellular dual-drug delivery. J. Mater. Chem. 2012, 22, 22028-22036. [CrossRef]

50. Gan, L.S.; Zheng, D.J.; Liu, Q.; Zhou, J.; Zhang, M.Z.; Yao, W.; Shao, B.H.; Mo, J.X.; Zhou, C.X. Eight new cycloartane triterpenoids from Beesia calthifolia with hepatoprotective effects against D-galactosamine induced L02 cell damage. Bioorg. Med. Chem. Lett. 2015, 25, 3845-3849. [CrossRef]

51. Liu, J.X.; Shen, S.N.; Tong, Q.; Wang, Y.T.; Lin, L.G. Honokiol protects hepatocytes from oxidative injury through mitochondrial deacetylase SIRT3. Eur. J. Pharmacol. 2018, 834, 176-187. [CrossRef]

52. Shen, S.N.; Liao, Q.W.; Feng, Y.; Liu, J.X.; Pan, R.L.; Lee, S.M.Y.; Lin, L.G. Myricanol mitigates lipid accumulation in 3T3-L1 adipocytes and high fat diet-fed zebrafish via activating AMP-activated protein kinase. Food Chem. 2019, 270, 305-314. [CrossRef]

53. Li, D.; Liu, Q.Y.; Sun, W.; Chen, X.P.; Wang, Y.; Sun, Y.X.; Lin, L.G. 1,3,6,7-tetrahydroxy-8-prenylxanthone ameliorates inflammatory responses resulting from the paracrine interaction of adipocytes and macrophages. Br. J. Pharmacol. 2018, 175, 1590-1606. [CrossRef] [PubMed]

Sample Availability: Samples of all the isolated compounds are available from the authors.

(C) 2019 by the authors. Licensee MDPI, Basel, Switzerland. This article is an open access article distributed under the terms and conditions of the Creative Commons Attribution (CC BY) license (http:/ / creativecommons.org/licenses/by/4.0/). 